\title{
COVID-19 pandemic: A narrative review on possible prophylactic role of AYUSH- Unani system and medicinal plants
}

\author{
Mohd. Kashif Husain * \\ Survey of Medicinal Plants Unit, National Research Institute of Unani Medicine for Skin Disorders (NRIUMSD), Hyderabad-500038, \\ T.S., India

\section{Article Info} \\ Article history \\ Received 26 October 2021 \\ Revised 13 December 2021 \\ Accepted 14 December 2021 \\ Published Online 30 December 2021 \\ Keywords \\ COVID-19 \\ Indian traditional medicine \\ AYUSH-Unani medicinal plants

\begin{abstract}
Coronavirus disease (COVID-19), caused by SARS-CoV-2 (Severe Acute Respiratory Syndrome Coronavirus2), has been the cause of global pandemic and a matter of concern for a larger population on this planet. Despite recent reports of substantial research towards the development of viable therapies to combat this global health issue, there is still no approved therapy to cure SARS-CoV-2. India is witnessing a third wave of coronavirus (due to Omicron variant), with daily rise in COVID-19 cases in the states with large population may rise exponentially and lead to community transfer. The rapid mutations of the virus and never-ending new strains (Delta, Omicron) have now become more critical and it is hard to tell, how this situation will manifest in future. The increase in COVID-19 cases has put a pressure on the healthcare system, leading to uncertainty in the minds of the people. Indian systems of traditional medicines-AYUSH have a wide-ranging potential for being used in these tough times either as adjuvant therapy or prophylactically due to their age-old use in the community, classical references/text, pharmacopeias and scientific evidence about their safety and clinical efficacy. AYUSH-Unani (GrecoArabian medicine) originated with the concept and teachings of Hippocrates and developed during the middle ages, which employs natural drugs of plant, animal and mineral origin for the treatment during the epidemic. An attempt has been made to give a brief overview on AYUSH-Unani concept of epidemic and its preventive measures by the use of single plant origin drugs/compound formulations, having
\end{abstract} \\ pharmacological activities.
}

\section{Introduction}

Coronavirus disease (COVID-19) is a highly infectious disease which is caused by a novel coronavirus called SARS-CoV-2 (Severe acute respiratory syndrome coronavirus), a name given by the International Committee on Taxonomy of Viruses (Sun et al., 2020). The World Health Organization (WHO) first learnt of this newfangled virus on 31 December 2019, following a report of a cluster of cases of 'viral pneumonia' in Wuhan city (Hubei Province) of People's Republic of China (WHO, 2020).

The current and still ongoing COVID-19 disease is the third coronavirus epidemic of zoonotic origin which happens to occur in this century (Sun et al., 2020), and spread sharply to nearly seventytwo countries in a time span of less than three months (Chinazzi et $a l ., 2020)$ and later to 180 countries including India. It has affected 'all the continents except Antarctica' (Acharya, 2020). The WHO declared the COVID-19 disease as global 'pandemic', on March 12, 2020.

Coronaviruses are mostly zoonotic, meaning they are transmitted from animals to humans. Coronaviruses are a large family of viruses that cause less severe common cold to more dreadful diseases such

\section{Corresponding author: Dr. Mohd Kashif Husain}

Scientist, Survey of Medicinal Plants Unit, National Research Institute of Unani Medicine for Skin Disorders (NRIUMSD), Hyderabad-500038, India

E-mail: kashifptc@gmail.com

Tel.: +91-7382189745

Copyright () 2021 Ukaaz Publications. All rights reserved.

Email: ukaaz@yahoo.com; Website: www.ukaazpublications.com as Middle East respiratory syndrome (MERS-CoV, 2012) and severe acute respiratory syndrome (SARS-CoV, 2002-03), and cause viral 'pneumonia'- in human beings (Èivljak et al., 2020). The SARSCoV-2 is a coronavirus that is very similar to the SARS. While the SARS coronavirus is thought to be an animal virus from an as-yetuncertain animal reservoir, perhaps bats, that spread to other animals (civet cats) and first infected humans in the Guangdong province of southern China in 2002. The MERS coronavirus was reported to be passed on to humans from dromedary camels in Saudi Arabia (2012). There is possibility that SARS-CoV-2 is a batorigin coronavirus that has been transmitted to humans by undetermined intermediate animal host or wild animals or through spilled over fleece (Zowalaty et al., 2020; Ahmed et al., 2020).

Globally, researchers are working hard to develop the effective treatments for COVID-19. Most of the clinical trials are either on going or enrolling new patients, and new ones are regularly being added on day-to-day basis, as the cases are still multiplying globally due to different strains. The drugs being tested range from repurposed flu treatments to some failed drugs, or successful drugs as used for the treatment of malaria (developed decades ago) (Lythgoe and Middleton, 2020). In the absence of any definitive therapeutic strategy, medical researchers/scientists are working tirelessly to not only save human lives but also search for the effective treatment modalities against the fatal viral disease.

Considering the current situation of pandemic, the 'traditional systems of medicine (TSM)' which are mainly practiced in countries like India, Japan, China, South Korea and Iran are being explored as 
an alternative to provide preventive, supportive and rehabilitative care to the COVID-19 patients, which has been widely used in China during the recent past epidemic outbreaks such as SARS and H1N1 influenza (Luo et al., 2020). Three countries; India, China, and South Korea, had initially issued the detailed guidelines in the year 2020 itself to use the traditional regimens for the prevention and management of COVID-19 (Ang et al., 2020).

The Indian TSM is one of the oldest systems of medicine exist in the world, played avital role in providing healthcare services to human civilization, since its inception. AYUSH-Ayurveda, Yoga and Naturopathy, Unani, Siddha, Homoeopathy and Sowa Rigpa, system of India, has the exclusive peculiarity of its own officially well recognized TSM. AYUSH systems are based on the definite concept and philosophies to achieve a healthy life style, promotion of health with conventional and established ideas for the prevention of diseases. The basic treatment approach of all these systems is holistic and the pharmacological modalities are based on the natural products of mainly plants, followed by animals and mineral origin. During the pandemic, there is vival of interest happened in AYUSH systems, which helped the nation as earlier in the case of pandemic crisis (Spanish flu, plague, etc.) in early $21^{\text {st }}$ century. Among Indian TSM, AYUSH-Unani (Greco-Arabian System of Medicine) originated with the concept and teachings of Hippocrates, improved and systematized by Arabian physicians. During Mughal period $\left(11^{\text {th }}\right.$ $13^{\text {th }}$ century), AYUSH-Unani system was introduced to India and further propagated by the teachings and practice of the Unani scholars (Husain et al., 2017).

Considering the above points, an attempt has been made to discuss a brief overview of COVID-19 and AYUSH-Unani concept of epidemic and its preventive measures as a possible alternative strategy in the prophylactic management of the SARS-CoV-2 infection by the use of natural plant origin drugs.

\section{Route of transmission, pathogenesis and symptoms}

It has now been established that that SARS-CoV-2 has a structural similarity of $96.2 \%$ with a bat coronavirus (CoV RaTG13) and $79.5 \%$ similarity with SARS-CoV. However, the spike (S) glycoprotein of SARS-CoV-2 has ten-twenty (10-20) times more affinity to human ACE-2 receptors as compared to SARS-CoV, leading to more chances of human-to-human mode of transmission (Guo et al., 2020) through respiratory droplets or close contacts. The route of human-to-human pathogen transmission was suggested based on the previous reports and experiences inferred from the two earlier coronavirus $(\mathrm{CoV})$ epidemics (Li et al., 2020). A high numbers of leukocytes (L) and higher pro-inflammatory cytokines in plasma of COVID-19 diagnosed patients were reported (Mardani et al., 2020). The basic pathogenesis of COVID-19 infection lesion is found in respiratory system wherein the virus multiplies rapidly and causes severe viral 'pneumonia' (Yang et al., 2020). Increased concentrations of proinflammatory cytokines; interleukins (IL-6 and IL-10), granulocytecolony stimulating factor (G-CSF), macrophage inflammatory protein (MIP) $1 \alpha$, tumor necrosis factor (TNF)- $\alpha$,) and monocyteche moattractant protein-1(MCP1) in plasma have been reported in critical cases of COVID-19 (Yuki et al., 2020). The cytokine storm cause ARDS-acute respiratory distress syndrome, a fatal uncontrolled systemic inflammatory response due to the release of large quantity of pro-inflammatory cytokines and chemokines by the immune effector cells in SARS-CoV2 infected persons (Guo et al., 2020).
The antibody profile against the SARS-CoV-2 virus revealed a typical pattern of antibody production (IgM and IgG) similar to common viral infections. The SARS-specific IgG antibodies supposed to perform a protective role, as it lasts for a longer time as compared to IgM antibodies, which disappear at the end of twelve weeks. The current reports of SARS-CoV-2-infected patient's peripheral blood showed a significant reduction in the number of $\mathrm{T}$ cells $(\mathrm{CD} 4+$ and $\mathrm{CD} 8+)$ and activation of pro-inflammatory cytokines

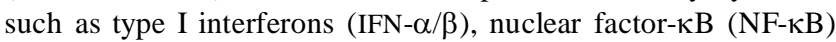
and (IRF3) interferon regulatory factor 3 (Li et al., 2020).

COVID-19 patients presented no symptoms (asymptomatic) or non-specific symptoms from severe viral 'pneumonia' leading to death. However, the most common symptoms varied from person -to-person and include high-grade fever, cough (non-productive), fatigue, diarrhea, dyspnea, myalgia, low oxygen level due to lung damage, decreased leukocyte (L) counts, and radiographic findings of pneumonic patches, mostly similar to the symptoms of MERS$\mathrm{CoV}$ and SARS-CoV infections, leading to the complications like ARDS, cardiac arrest/acute heart injury, and secondary deadly infections (WHO, 2021; Guo et al., 2020; Rothan and Byrareddy, 2020).

\section{Concept of infectious diseases and epidemics in AYUSH- Unani system}

As per the standard terminology published by the CCRUM, the equivalent term for 'wabâ' (contaminated or putrefied changes in the air) is epidemic (Anonymous, 2012; Jurjani, 2010). The concept of microbes came into existence after the discovery of microscope that's why the disease-causing substances do not find a direct place of reference in AYUSH-Unani literature. However, the Unani scholars, like Avicenna (Ibn-e-Sina) had sufficient understanding that certain bad substance - pathogenic organisms (ajsâm khabîtha) can move from the diseased to healthy persons in a very short period and may cause certain diseases (Sina, 2010). The theory of -'contagion' is endorsed by many Unani scholars. The historical events testify that many infectious diseases such as; smallpox, meningitis, leprosy, tuberculosis and rabies were widespread in olden days. Hippocrates described the clinical manifestations of various infectious, diseases, now which are named as; influenza tuberculosis, mumps and diphtheria, malaria. Hippocrates also stated that certain infectious diseases such as; cholera, plague and chlamydia spreads through a noxious form of bad air which contains harmful vapours or poisonous elements that enters in the human body by inhalation or through skin pores

According to Galen (Jalinoos 131-199 CE), 'a physician should always keep an eye on changes of weather and air'. WHO (May 1970) recognized a treatise-'Book on Smallpox and Measles'(Kitab fi al-jadari wa-al-hasbah /DeVariolis et Morbiliis)' by Zakariya Razi (865-925 CE), as the first scientific treatise on the subject (Islam, 2018). It described the modes of spread of the smallpox and measles diseases and its distinct diagnosis. Razes (Razi) is regarded as a great epidemiologist, who elaborated many aspects of epidemic diseases and mentioned in Liber Continens (Kitab al-Hawi), that "when zoonotic diseases are epidemic, the human being should avoid being in close contact with animals'.

Avicenna (Ibn-e-Sina) had knowledge of bad substance (microbes) being present on the dead body that could infect others. According 
to Ibn-e-Sina,-'air and water are contaminated only after amalgamation of bad substances (Ajsâm khabîtha), which does not happen otherwise and such contamination can also be carried if the dead bodies of the persons dying due to epidemic (wabâ) are not appropriately disposed (Sina, 2010). A Spanish scholar, Ibn Khatima (1369 CE) mentioned in his treatise, namely; 'Succeeding in clarifying pest disease (Tahsil garaal qasid fi-tafsil al-maraal wafid)' that 'the human body who comes in close contact with a plague patient may cause disease and will start suffering from the same symptoms'. It is clear that the Unani scholars of that time were aware of the presence of some substance (micro-organisms) in the environment that is responsible for disease transmission (Cambra, 2018; Nikhat and Fazil, 2020).

Zakariya Razi (925 CE) mentioned that 'there would always be something common in patients of epidemics, whether food, a place, drink or travel history' (Razi, 2008). During the $14^{\text {th }}$-century plague pandemic, an Arabian scholar, Ibn Khatib (1374 CE) stated that 'most of the people who come in contact with a plague victim will die'. He further states, 'the disease spreads through clothes, jewelry and utensils' (Ober and Aloush, 1982; Nikhat and Fazil, 2020), thus advocating the transmission of disease through fomites.

A Persian scholar, Najeebuddin Samarqandi $(1222 \mathrm{CE})$ of the $13^{\text {th }}$ century has mentioned about a type of epidemic influenza in his treatise. The translated version of 'the book of causes and symptoms' (Al-asbab wa-Alamat), published by the name of 'Sharah Asbab', the epidemic influenza is mentioned by the name of Nazla-e-Wabaiya, which is associated with nasal irritation, sore throat, sneezing, fever, malaise, and weakness. A person of epidemic influenza (Nazla-e-Wabaiya) may also suffer from diarrhoea, and delirium. If pleurisy and pneumonia are present, the prognosis may worsen (Samarqandi, 2010; Nikhat and Fazil, 2020).

\section{Importance of medicinal plants in the management of epidemic influenza in AYUSH-Unani system}

The management of epidemic influenza in Unani system of medicine is mentioned in detail and it suggests to use the decoction of plant origin drugs like; Cordia dichotoma (sapistan) Cydonia oblonga (behidana), Sisymbrium irio (khaksi) and Ziziphus jujube (unnab) as the dose mentioned in Table 1.

The seeds of Myrtus communis (habb-ul aas) and translucent white substance of Bambusa bambos (tabasheer) are suggested to use in the case of disease related diarrhea. Seed paste of Lactuca sativa (Sheera tukhm-e-kahu) may prescribe to relieve thirst (Table 1). In case of pneumonia or pleurisy, sap of Aloe vera, thread (stigma) of Crocus sativus along with some specific medication (Qairooti-aaradKarsana) are mixed together and may be apply slight warm on the chest, wrapped with a cotton bandage (Baghdadi, 2004; Samarqandi, 2010; Nikhat and Fazil, 2020). All these plant origin drugs have immunomodulatory or anti-inflammatory, or antipyretic and other activities, which have been reported by many workers from timeto-time using modern pharmacological techniques (Table 1).

Table 1: Plant origin AYUSH-Unani drugs for the management of epidemic influenza

\begin{tabular}{|c|c|c|c|c|c|}
\hline S. No. & $\begin{array}{l}\text { Botanical and Unani } \\
\text { name, family, part used }\end{array}$ & $\begin{array}{l}\text { Mode of administration } \\
\text { (Unani) and drug form }\end{array}$ & Active ingredients & $\begin{array}{l}\text { Pharmacological } \\
\text { activity }\end{array}$ & References \\
\hline 1. & $\begin{array}{l}\text { Aloe vera (L.) Burm. f. } \\
\text { (Liliaceae) Elwa, Leaf, Sap }\end{array}$ & Local application on chest & $\begin{array}{l}\text { Anthraquinones, } \\
\text { Mannose-6-phos- } \\
\text { phate anthrones }\end{array}$ & Anti-inflammatory & $\begin{array}{l}\text { Sina, 2010; } \\
\text { Arain, } 2016\end{array}$ \\
\hline 2 . & $\begin{array}{l}\text { Bambusa bambos (L.) Voss } \\
\text { (Bambusaceae) Tabasheer; } \\
\text { translucent white substance, } \\
\text { (silica and water) obtained } \\
\text { from the noodal joints }\end{array}$ & Decoction oral & $\begin{array}{l}\text { Adipic acid ester, } \\
\text { polyphenols, } \\
\text { coumaran, palmitic } \\
\text { acid, } \alpha \text {-elemol }\end{array}$ & $\begin{array}{l}\text { Antidiarrhoeal } \\
\text { Antihelminthic, } \\
\text { Anti-inflammatory }\end{array}$ & $\begin{array}{l}\text { Samarqandi, } 2010 \text {; } \\
\text { Vairappan et al., } \\
\text { 2015; Sina, } 2010\end{array}$ \\
\hline 3. & $\begin{array}{l}\text { Cordia dichotoma G. Forst. } \\
\text { (Cordiaceae) Sapistan/ } \\
\text { Lasora, Fruit }\end{array}$ & Decoction oral & $\begin{array}{l}\alpha \text {-amyrinstaxifolin-3- } \\
5 \text {-dirhamnoside }\end{array}$ & $\begin{array}{l}\text { Antimicrobial, } \\
\text { Antioxidant, } \\
\text { Antiulcer }\end{array}$ & $\begin{array}{l}\text { Sina, 2010; Oza } \\
\text { and Kulkarni, } \\
2017\end{array}$ \\
\hline 4. & $\begin{array}{l}\text { Crocus sativus L. (Iridaceae) } \\
\text { 'Za'fran Dried Stigma' }\end{array}$ & Local application on chest & $\begin{array}{l}\text { Crocin, crocetin, saf- } \\
\text { ranal, and picrocrocin }\end{array}$ & $\begin{array}{l}\text { Anti-inflammatory } \\
\text { Antioxidant, } \\
\text { Anticancer, } \\
\text { Antitumor activity, } \\
\text { Protection from } \\
\text { genotoxicity } \\
\text { cardioprotection, } \\
\text { Antidiabetic, } \\
\text { Prevention of } \\
\text { respiratory disorders }\end{array}$ & $\begin{array}{l}\text { Bolhassani, 2018; } \\
\text { Bukhari et al., } \\
2018 \text {; Samarqandi, } \\
2010\end{array}$ \\
\hline 5 . & $\begin{array}{l}\text { Cydonia oblonga Mill. } \\
\text { (Rosaceae) Behidana Seeds }\end{array}$ & Decoction oral & $\begin{array}{l}\text { Flavones; isoschafto- } \\
\text { side caffeoylquinic } \\
\text { acids tannins, } \\
\text { glycosides }\end{array}$ & $\begin{array}{l}\text { Anti-inflammatory } \\
\text { Antimicrobial }\end{array}$ & $\begin{array}{l}\text { Ashraf et al., } 2016 \\
\text { Essafi-Benkhadir, } \\
\text { et al., 2012; } \\
\text { Fattouch, 2007; } \\
\text { Sina, 2010 }\end{array}$ \\
\hline
\end{tabular}




\begin{tabular}{|c|l|l|l|l|l|}
\hline 6. & $\begin{array}{l}\text { Lactuca sativa L. } \\
\text { (Asteraceae) Tukhm-e- } \\
\text { Kahu seeds }\end{array}$ & Oral & $\begin{array}{l}\text { Sesquiterpene } \\
\text { lactones-lactucin, } \\
\text { lactucopicrin }\end{array}$ & $\begin{array}{l}\text { Antioxidant, } \\
\text { Anti-inflammatory, } \\
\text { Antimicrobial, } \\
\text { Analgesic, Sedative } \\
\text { properties }\end{array}$ & $\begin{array}{l}\text { Anilakumar } \text { et al., } \\
2017 ; \text { Sina, 2010 }\end{array}$ \\
\hline 7. & $\begin{array}{l}\text { Myrtus communis L. } \\
\text { Myrtaceae Habb-ul as Berry } \\
\text { (Seeds) }\end{array}$ & Decoction oral & $\begin{array}{l}\text { Phenolic acids (gallic } \\
\text { acid, ellagic acid), } \\
\text { flavonols; myricetin } \\
\text { glycosides, quercetin } \\
\text { and kaempferol, } \\
\text { glycosides }\end{array}$ & $\begin{array}{l}\text { Gastrointestinal } \\
\text { motility inhibition, } \\
\text { Antioxidant }\end{array}$ & $\begin{array}{l}\text { Franco } \text { et al., } \\
2019 ; \text { Jabri } \text { et al., } \\
2016 ; \text { Sina, 2010 }\end{array}$ \\
\hline 8. & $\begin{array}{l}\text { Sisymbrium irio L. } \\
\text { (Brassicaceae) Khaksi seeds }\end{array}$ & Mix after decoction & $\begin{array}{l}\text { Apigenin, } \beta \text {-sitosterol, } \\
\text { stigmasterol }\end{array}$ & $\begin{array}{l}\text { Antipyretic, } \\
\text { Analgesic and } \\
\text { Antimicrobial }\end{array}$ & $\begin{array}{l}\text { Vohora } \text { et al., 1980 } \\
\text { Al-Jaber, 2011; } \\
\text { Sina, 2010 }\end{array}$ \\
\hline 9. & $\begin{array}{l}\text { Ziziphus jujube Mill. } \\
\text { (Rhamnaceae) Unnab fruit }\end{array}$ & Decoction oral & $\begin{array}{l}\text { Flavonoids, } \\
\text { Polysaccharides, } \\
\text { Terpenoids, saponins }\end{array}$ & $\begin{array}{l}\text { Anti-inflammatory } \\
\text { Immunemodulatory }\end{array}$ & $\begin{array}{l}\text { Chen and Tsim, } \\
2020 ; \text { Sina, 2010 }\end{array}$ \\
\hline
\end{tabular}

\section{Common medicinal plants in AYUSH-Unani system and its possible prophylactic role in COVID-19}

The advent of deadly infectious diseases like COVID-19 caused by novel and mutated virus strains (Delta, Omicron) resistant to frequently used routine antiviral medications is a growing problem at global level, especially in immune-compromised patients. Due to lack of standard treatment process, people have put faith again in the TSM, especially Indian, AYUSH-Ayurveda, Unani and Siddha systems (Weeks, 2020). Besides Indian, other systems such as; TCM-Traditional Chinese medicine, Kampo medicine-Traditional Japanese medicine and Traditional European medicine system are found to be promising base for the discovery of new antiviral drugs (Sohail et al., 2021; Reichling and Schnitzler, 2011).

The herbal formulations used in AYUSH-Ayurveda, Unani, TCM and Kampo medicines have been used to mitigate the symptoms associated with the viral outbreak. Clinical trials yet to confirm the efficacy of these systems; however, isolated phytochemicals have revealed some encouraging results based on their mode of actions inside the human body (Zhang, 2020).

Therefore, in the recent years, particularly since the onset of pandemic (last two years), a large number of experiments confirming the antiviral efficacies of medicinal plant extracts, and/or related physiologically active ingredients, secondary metabolites, viz, anthraquinones flavonoids and naphthodianthrones, have been reported to show antiviral activities or reduced the COVID-19 associated symptoms (El-Toumy et al., 2018; Jabborova et al., 2019; Sohail et al., 2021).

The AYUSH-Unani system of medicine was founded in Greece and further developed by Arabs into an elaborated system (medical science) based on the philosophy and teachings framework of Hippocrates (Buqrat) and Galen (Jalinoos). The Unani (GrecoArab) system has been officially recognized in India and is expanded during the Mughal period. Of all the Indian systems, Unani has also been recognized by the WHO as an alternative system of medicine to cater the healthcare needs of the human population. Unani system is based on Hippocratic philosophy of four humours, viz., yellow bile, blood, phlegm, and black bile, and the four characteristics (hot, cold, wet, and dry) of human body conditions (Husain et al., 2017). The infectious and epidemic diseases are caused by the invasion of infection in the form of foreign bodies (Ladia or adva), that disturbs the humours, vital heat (Hararat-eGharizia), liver, heart, stomach and other vital organs (Khan 1981). The eminent scholars (Avicenna, Galen, Razes) of the AYUSHUnani system had advocated the use of certain natural drugs (single/ compound formulations), known to improve the host-immunity especially, during the outbreak of epidemics, endemics and pandemics. Ismail Jurjani (1136 CE) advocated the use of 'Tiryaq' during epidemics. It is useful to strengthen the heart and also retain strong body faculties (Jurjani, 2010).

In AYUSH-Unani system, single drugs or compound formulations have been well documented in classical Unani literature and had been used during the epidemic. The single drugs, mostly obtained from the medicinal and aromatic plants, are either recommended by Ministry of AYUSH to use as it is (as per guidelines) or may be used in Unani compound formulations as ingredients. These immunebooster and other drugs give symptomatic relief in upper respiratory tract infections and have known pharmacological activities (antiviral and anti-inflammatory potential) which may give the leads against COVID-19 disease. Some of the important medicinal plants/drugs are (Anonymous 2020a, 2020b; Husain et al., 2020, Nikhat and Fazil, 2020) as;

\subsection{Caesalpinia bonduc (L.) Roxb. (Fabaceae) - (Karanjwa)}

Useful plant part: Nuts and leaves

Active ingredient: Caesalpins, bonducellin and citrulline

Pharmacological activities: Antipyretic, antimicrobial, antiinflammatory and immunomodulator (Husain et al., 2020)

Dose: 3 to $5 \mathrm{~g}$

\subsection{Cordia dichotoma G. Forst. (Cordiaceae) - Sapistan/Lasora}

Useful plant part: Fruit

Active ingredient: $\alpha$-amyrins, betulin, octacosanol, lupeol3rhamnoside, $\beta$-sitosterol-3glucoside, hentricontanol

Pharmacological activities: Immunomodulator, tracheal smooth muscle relaxant and antioxidant

Dose: 9 pieces 


\subsection{Cydonia oblonga Mill. (Rosaceae)-Behidana}

Useful plant part: Seed

Active ingredient: Caesalpins, bonducellin and citrulline

Pharmacological activities: Immunomodulator, tracheal smooth muscle relaxant and antioxidant

Dose: $3-5 \mathrm{~g}$

\subsection{Ziziphus jujube Mill. (Rhamnaceae)-Unnab}

Useful plant part: Fruit

Active ingredient: Phenolics, flavonoids, triterpenic acids, polysaccha rides

Pharmacological activities: Antiinfluenza, immunomodulator and antioxidant

Dose: 5 pieces

\subsection{Emblica officinalis Gaertn. (Euphorbiaceae)-Amla}

Useful plant part: Fresh fruit pulp and the pericarp of dried mature fruits

Active ingredient: Polyphenols (ellagic acid, chebulinic acid, gallic acid, apeigenin, quercetin, flavonoids, triterpenic acids, polysaccharides)

Pharmacological activities: Memory enhancing, antioxidant, and anti-acetylcholineesterase (AChE), antidepressant

Dose: As per formulation 5.6 Tinospora cordifolia (Willd.) Hook. f. \& Thomson.
(Menispermaceae)-Gilo

Useful plant part: Stem, leaf

Active ingredient: Tinoscorside A and B, clerodane diterpene, tinoscorside $\mathrm{C}$, a diterpenoid lactones, cardiac glycosides,steroids, sesquiterpenoid, phenolics

Pharmacological activities: Antiviral, immunostimulator, antihyperglycemic, analgesis anti-inflammatory

Dose: 5-10 g

5.7 Cassia fistula L. (Caesalpiniaceae)-Khayarshamber

Useful plant part: Fruit pulp

Active ingredient: Anthraquinone glycosides, Biochanin A, Clerosterol

Pharmacological activities: Antiviral, antilishamanial, antioxidant, Anti-inflammatory

Dose: $10-20 \mathrm{~g}$ (pulp) for gargle

5.8 Nigella sativa L. (Ranunculaceae)-Kalonji

Useful plant part: Seed

Active ingredient: Thymoquinone (TQ), p-cymene, carvacrol and longifolene

Pharmacological activities: Antiviral, CNS depressant, antiinflammatory, and analgesic

Dose: $1-2 \mathrm{~g}$

\subsection{Artemisia absinthium L. (Asteraceae)-Afsanteen}

Useful plant part: Leaves, flower

Active ingredient: Bitter glucoside absinthin, absinthicacid, lactones, terpenoids (trans-thujone, $\beta$-terpinene

Pharmacological activities: Antiviral, antioxidant, anti-inflammatory, antitrypanosomal

Dose: 3-5 g

5.10 Cuscuta reflexa Roxb. (Convolvulaceae)-Tukhm-e-Kasoos

Useful plant part: Seeds

Active ingredient: Terpenoids, phenols and alkaloids, cuscutin, amarbelin, stigmasterol, $\beta$-sitosterol

Pharmacological activities: Antiviral, antimicrobial, analgesic, hypoglycemic, antioxidant, anti-inflammatory

Dose: $15 \mathrm{~g}$ (seeds)

5.11 Glycyrrhiza glabra L. (Fabaceae)-Aslassus/Mulethi

Useful plant part: Roots

Active ingredient: Glycyrrhizin, 2-b-glucuronosyl, glucuronic acid, and isoliquiritigenin-4-glucoside

Pharmacological activities: Antiviral, antimicrobial, antiinflammatory, antioxidant, antiangiogenic and antitumor

Dose: $5-10 \mathrm{~g}$

5.12 Zingiber officinale Rosc. (Zingiberaceae)-Zanjabeel

Useful plant part: Rhizome

Active ingredient: Gingerols and shogaols

Pharmacological activities: Antiviral, anti-inflammatory, antioxidant, analgesic, neuroprotective

Dose: $5 \mathrm{~g}$

5.13 Withania somnifera (L.) Dunal (Solanaceae)-Aswagandha Useful plant part: Root

Active ingredient: Withaferins, withnolides

Pharmacological activities: Anti-inflammatory, antioxidant, analgesic Dose: $5 \mathrm{~g}$

5.14 Curcuma longa L. (Zingiberaceae)-Zard Chob/Haldi

Useful plant part: Rhizome

Active ingredient: Curcuminoids-curcumin

Pharmacological activities: Anti-inflammatory, antioxidant, analgesic, anthelmintic

Dose: $5-6 \mathrm{~g}$

\subsection{Ocimum tenuiflorum L. (Lamiaceae)-Rehan}

Useful plant part: Leaf and whole plant

Active ingredient: Saponins, triterpenoids, flavonoids, and tannins; the phenolic compounds (rosmarinic acid, propanoic acid, apigenin and cirsimaritin) 
Pharmacological activities: Antifertility, anticancer, antidiabetic, antifungal, antimicrobial, cardioprotective

Dose: $5-6 \mathrm{~g}$

\subsection{Crocus sativus L. (Iridaceae)-Zafran}

Useful plant part: Style and stigma

Active ingredient: Safranal, zeaxanthin, lycopene, $\alpha$ - and $\beta$-carotene

Pharmacological activities: Antioxidant, anti-inflammatory antispasmodic, antiasthmatic, antirheumatic, antidepressant and antineuralgic

Dose: As per formulation

\section{Useful AYUSH-Unani compound formulations based on the plant origin drugs}

\subsection{Arq-e-Ajeeb}

Unani physicians have successfully prescribed-'Arq-e-Ajeeb', to treat the epidemic influenza alongwith other medication. Arq-eAjeeb (liquid) consists of menthol, thymol, and camphor. It is made by mixing equal quantity $(1: 1: 1)$ of extract of Mentha arvensis, Trachyspermum ammi, and Cinnamomum camphora. Menthol has shown anti-inflammatory activity (Zaia et al., 2016) while, thymol is a promising antiviral agent and is used topically to treat the herpetic infections (Lai et al., 2012).

\subsection{Lauq-Katan}

A sugar-based semisolid Unani formulation which is mainly consists of the seeds and oil of Linum usitatissimum (Flax/alsi/katan). This medication is primarily used for the treatment of lung diseases and respiratory disorders. Flax seeds chiefly contain $\alpha$-linolenic acid, reported to have anti-inflammatory, antiviral (Erdinest et al., 2012) and immunomodulatory activities (Miccadei et al., 2016).

\subsection{Lauq-Sapistan}

A semisolid, sugar-based polyherbal Unani formulation prescribed for the treatment of cough and cold, asthma and chronic respiratory disorders. It reduces the inflammation of the tonsils pharynx, and irritation due to infection. The main ingredient of this formulation is Cordia dichotoma (Sapistan/Lasora) which has exhibited antitussive and antiviral activities (Jamkhande et al., 2013). Another important component, Viola odorata (Banafsha) suppressed the viral load and increased the antiretroviral drug efficacy (Gerlach $e t$ al., 2019). Ziziphus jujube fruit, which contains betulinic acid, is another essential component of this formulation. Betulinic acid down regulated a cytokine, the interferon gamma (IFN $\gamma$ ) in mouse lungs, enhanced the immunity. Betulinic acid appeared to be a potential therapeutic agent for the viral infections (Hong et al., 2015).

\subsection{Triyaq-e-Araba}

"Tiryaq" means 'antidote and 'Arba' means four. It is an age-old Unani formulation, which has been used as an antidote against the poison and for prophylactic measures during epidemics (detoxifying agent). The four ingredients are; berries of Laurus nobilis, root of Gentiana lutea, roots of Aristolochia indica and gum of Commiphora myrrha (Loizzo et al., 2008), exhibited a strong antiviral activity against severe acute respiratory syndrome coronavirus (SARS-CoV).
Sinupret, polyherbal preparation, consist of Gentiana lutea as main ingredient, has shown strong inhibitory activity against the virus which causes acute respiratory infections, such as; adenovirus, respiratory syncytial virus, influenza, influenza A, parainfluenza virus, human rhinovirus B, and coxsackievirus (Glatthaar et al., 2019).

\subsection{Khamira Banafsha}

It is a semi-solid Unani formulation, used to treat, common cold, cough, catarrh, chest diseases and asthma. The main ingredient of this formulation is the decoction of flower of Viola odorata (Gul-eBanafsha), which contains flavonoid, glycosides, alkaloids, steroids, terpenes, saponins and tannins. Gul-e-Banafsha is used for treating of respiratory ailments, bronchitis, whooping cough, fever, skin conditions, cystitis, and throat infection. It is anti-inflammatory, diaphoretic, diuretic, emollient, expectorant, antipyretic and laxative properties. Further, V. odorata suppressed the viral load and increased the antiretroviral drug efficacy (Gerlach et al., 2019), decreased the thickness of the alveolar wall, hemorrhage area, and alter the epithelial lining of bronchioles of the lungs (Koochek et al., 2003).

\subsection{Sharbat Toot Siyah}

A trusted syrup of Unani medicine is an effective and time-tested herbal remedy that provides prompt relief in hoarseness of voice, throat pain, chest congestion and resolves the inflammatory conditions of upper respiratory tracts (URT), and improves the pitch of voice. It is composed of the juice of Morus nigra in a sugar base and is used to treat tonsillitis and sore throat. M. nigra has been reported as analgesic, anti-inflammatory and inhibited the pro-inflammatory cytokines (Chen et al., 2016) and exhibited enhanced immune-modulatory activity (Lim and Choi, 2019).

\section{Conclusion}

Medicinal plants are a source of countless compounds, having multidimensional chemical structures which made them superior to treat serious diseases also as an alternative medicine. Of these, some have already been reported as promising - 'lead compounds' for drug repurposing and discovery. Modern drug development is a costly and time-consuming process and is not practicable in the situation of the immediate global challenge in the form of pandemic and new viral strains. Therefore, drug repurposing strategies are being considered to develop safe and effective treatment regimens against the disease. Currently, an array of drugs used for the other health conditions are being studied for the treatment of COVID-19 in several hundred clinical trials around the globe.

The integrated approach of AYUSH-Unani system gives emphasis on the prevention of diseases through the modification in lifestyle, dietary management, enhancing the immunity, prophylactic interventions and simple cost-effective remedies based on the presentations and severity of the symptoms. Many plant origin single drugs and compound formulations have been mentioned in Unani system of medicine for the prevention and treatment of infectious diseases. Continued research on these plant origin drugs is necessary to promote their usage in clinical practice for the prevention or treatment of various illnesses. Since many of these medicinal plants exhibit, anti-inflammatory, analgesic, antiviral, antioxidant, and immune-modulatory activity, it would be advisable to 
consider them for the treatment of infectious diseases after scientific explorations and validation of their preclinical and clinical trials to prove their efficacy scientifically. The listed medicinal plants and AYUSH recommended formulations could help as the potential alternate therapeutics for the management and cure of infectious diseases.

\section{Acknowledgements}

Author gratefully acknowledged Professor Asim Ali Khan, DirectorGeneral, Central Council for Research in Unani Medicine (CCRUM), New Delhi, Ministry of AYUSH, Govt of India.

\section{Conflict of interest}

The author declares no conflicts of interest relevant to this article.

\section{References}

Acharya, K.P.(2020). Resource poor countries ought to focus on early detection and containment of novel corona virus at the point of entry. Clin. Epidemiol. Glob. Heal.https://doi.org/10.1016/ j.cegh.2020.03.001.

Ahmed, W.; Angel, N.; Edson, J.; Bibby, K.; Bivins, A.; O’Brien, J.W.; Choi, P.M.; Kitajima, M.; Simpson, S.L.; Li, J.; Tscharke, B.; Verhagen, R.; Smith, W.J.M.; Zaugg, J.; Dierens, L.; Hugenholtz, P.; Thomas, K.V. and Mueller, J.F. (2020). First confirmed detection of SARS-CoV-2 in untreated wastewater in Australia: A proof of concept for the wastewater surveillance of COVID-19 in the community. Sci. Total Environ., 1:728:138764. doi: $10.1016 /$ j.scitotenv.2020.138764.

Al-Jaber, N.A. (2011). Phytochemical and biological studies of Sisymbrium irio L. growing in Saudi Arabia, Journal of Saudi Chemical Society, 15(4):345-350. https://doi.org/10.1016/ j.jscs.2011.04.010.

Ang, L.; Lee, H.W.; Choi, J.Y.; Zhang, J. and Lee, M.S. (2020). Herbal medicine and pattern identification for treating COVID-19: A rapid review of guidelines. Integr. Med. Res., 9(2):100-407. doi:10.1016/ j.imr.2020.100407

Anilakumar, K.R.; Harsha, S.N.; Mallesha and Sharma R.K. (2017). Lettuce: A promising leafy vegetable with functional properties. Defence Life Sci. J., 2(2):178-185, DOI:10.14429/dlsj.2.11357.

Anonymous (2012). Standard Unani Medical Terminology. New Delhi: CCRUM, Dept. of AYUSH, Ministry of $\mathrm{H}$ and FW, Govt. of India, 2012: XVII, 148:157-8.

Anonymous (2020a). Guidelines for Unani practitionersfor COVID-19, Ministry of AYUSH Ayush Bhawan, INA, New Delhi.

Anonymous (2020b). Improve your immunity through Unani medicine, Central Council For Research in Unani Medicine (CCRUM), Ministry of AYUSH, Government of India, New Delhi.

Arain, I.U.; Husnain, A. and Talat, A. (2016). Effects of Aloe vera in local massage oils in alternative medicine for the treatment of joint pains: A double blind study. Ann. King Edward Med. Univ., 22:8. https://doi.org/10.21649/akemu.v22i1.789.

Ashraf, M.U.; Muhammad G.; Hussain M.A. and Bukhari, S.N.A. (2016) Cydonia oblonga M., A medicinal plant rich in phytonutrients for pharmaceuticals. Front. Pharmacol., 7:163. doi: 10.3389/fphar. 2016.00163 .

Baghdadi, I. H. (2004). Kitab al-Mukhtarat fil-Tib. Central Council for Research in Unani Medicine (CCRUM), New Delhi.
Bolhassani, A. (2018). Bioactive components of saffron and their pharmacological properties. Edt: Atta-ur-Rahman,Studies in Natural Products Chemistry, Elsevier, 58, Pages 289-311,https:/ /doi.org/10.1016/B978-0-444-64056-7.00010-6.

Bukhari, S.I.; Manzoor, M. and Dhar, M.K. (2018). A comprehensive review of the pharmacological potential of Crocus sativus and its bioactive apocarotenoids. Biomed. Pharmacother., https://doi.org/10.1016/ j.biopha.2017.12.090.

Cambra, L.M.A. (2018). The causes of the black death described by Ibn Khatima in his work Tahsil Al-Garad. Am. Res. J. English Lit., 4. https://doi.org/10.21694/2378-9026.18015.

Chen, J. and Tsim, K.W.K. (2020). A review of edible Jujube, the Ziziphus jujuba fruit: A heath food supplement for anemia prevalence. Front. Pharmacol., 11:593-655. doi: 10.3389/fphar.2020.593655.

Chen, H.; Pu, J.; Liu, D.; Yu, W.; Shao, Y. and Yang, G. (2016). Antiinflammatoryand antinociceptive properties of flavonoids from the fruits of black mulberry (Morus nigra L). PLoS One, 11(4): 153-280. doi:10.1371/journal.pone.0153080.

Chinazzi, M.; Davis, J.T.; Ajelli, M.; Gioannini, C.; Litvinova, M.; Merler, S.; Pastore, Y,; Piontti,A.; Mu, K.; Rossi, L.; Sun, K.; Viboud, C.; Xiong, X.; Yu, H.; Halloran, M.E.; Longini, I.M. and Vespignani, A., (2020). The effect of travel restrictions on the spread of the 2019 novel coronavirus (COVID-19) outbreak. Science, 80:97-57 https://doi.org/10.1126/ science.aba9757.

Èivljak, R.; Markotiæ, A. and Kuzman, I., (2020). The third coronavirus epidemic in the third millennium: What's next? Croat. Med. J., 61:1-4. https://doi.org/10.3325/cmj.2020.61.1.

El-Toumy SA.; Salib J Y.; El-Kashak WA.; Marty , Bedoux G. and Bourgougnon, N. (2018). Antiviral effect of polyphenol rich plant extracts on herpes simplex virus type 1. Food Sci. Human Wellness, 7(1):91101, https://doi.org/10.1016/j.fshw.2018.01.001.

Erdinest, N.; Shmueli, O.; Grossman, Y.; Ovadia, H. and Solomon, A. (2012). Anti-inflammatory effects of alpha linolenic acid on human cornealepithelial cells. Invest. Ophthalmol. Visual Sci., 53(8):43964406. doi:10.1167/iovs.12-9724

Essafi-Benkhadir, K,; Refai, A.; Riahi I.; Fattouch S.; Karoui, H. and Essafi, M. (2012). Quince (Cydonia oblonga Miller) peel polyphenols modulate LPS-induced inflammation in human THP-1-derived macrophages through NF- $\kappa \mathrm{B}$, p38MAPK and Akt inhibition. Biochem. Biophys. Res. Commun. 418(1):180-185.

Fattouch S,; Caboni P.; Coroneo, V.; Tuberoso, C.I.; Angioni, A.; Dessi, S.; Marzouki, N. and Cabras, P. (2007). Antimicrobial activity of Tunisian quince (Cydonia oblonga Miller) pulp and peel polyphenolic extracts. J. Agric. Food Chem., 55(3):963-969.

Franco, A.M.; Tocci, N.; Guella, G.; Dell'Agli, M.; Sangiovanni, E.; Perenzoni, D.; Vrhovsek, U.; Mattivi, F. and Manca, G. (2019). Myrtle Seeds (Myrtus communis L.) as a rich source of the bioactive ellagitannins oenothein B and eugeniflorin D2.ACS omega, 4(14):15966-15974 DOI: 10.1021 /acsomega.9b02010.

Gerlach, S.L.; Chandra, P.K.; Roy, U.; Gunasekera, S.; Göransson, U.; Wimley, W.C.; Braun, S.E. and Mondal, D. (2019). The membrane-active phytopeptide cycloviolacin O2 simultaneously targets hiv-1infected cells and infectious viral particles to potentiate the efficacy of antiretroviral drugs. Medicines (Basel), 6(1):33. doi: $10.3390 /$ medicines 6010033 .

Glatthaar, B.; Saalmüller, A.; Haunschild, J. and Amon, A. (2009). Antiviral activity of a composition of Gentiana lutea L., Primula veris L., Sambucus nigra L., Rumex spec. and Verbena officinalis L. (Sinupret@) against viruses causing respiratory infections. European J. Integ. Medicine., 1(4). doi: 10.1016/j.eujim. 2009.08.070. 
Guo, Y.R.; Cao, Q.D.; Hong, Z.S.; Tan, Y.Y.; Chen, S.D.; Jin, H.J.; Tan, K. Sen; Wang, D.Y. and Yan, Y. (2020). The origin, transmission and clinical therapies on coronavirus disease 2019 (COVID-19) out break: An update on the status. Mil. Med. Res., 7:11. https://doi.org/10.1186/ s40779-020-00240-0.

Hong, E. H.; Song, J. H.; Kang, K. B.; Sung, S. H.; Ko, H. J. and Yang, H. (2015) Anti-influenza activity of betulinic acid from Zizyphus jujuba on influenzaA/PR/8 virus. Biomol. Ther., 23(4):345-349. doi:10.4062/ biomolther.2015.019

Husain, M.K.; Khalid, M.; Pratap, G. P. and Kazmi, M. H. (2017). Relevance of traditional unani (Greco-Arab) system of medicine in cancer: An update. In: Anticancer Plants: Clinical Trials and Nanotechnology (eds. Akhtar M., Swamy M.). Springer, Singapore. pp:273-302. https://doi.org/10.1007/978-981-10-8216-0_10

Husain, M.K.; Pratap, G. P.; Alam, M.; Javed, G. and Kazmi, M. H. (2020). Botany, traditional uses and pharmacological importance of Karanjwa (Caesalpinia bonduc (L.) Roxb.): A possible prophylactic AYUSHUnani single drug for the management of COVID-19. Int. J. Herb. Med., 8(6):63-69

Islam, A., (2018). Origin and development of Unani medicine: An analytical study. Intellect. Discourse 26:23-49.

Jabborova, D.; Davranov, K. and Egamberdieva, D. (2019). Antibacterial, antifungal, and antiviral properties of medical plants. In medically important plant biomes: Source of secondary metabolites, pp: 51-65. Singapore: Springer.

Jabri, M.A.; Rtibi, K.; Sakly, M.; Marzouki, L. and Sebai, H., (2016). Role of gastrointestinal motility inhibition and antioxidant properties of myrtle berries (Myrtus communis L.) juice indiarrhea treatment. Biomed. Pharmacother., 84:1937-1944. https://doi.org/10.1016/ j.biopha.2016.11.008.

Jamkhande, P. G.; Barde, S. R.; Patwekar, S. L. and Tidke, P. S. (2013). Plant profile, phytochemistry and pharmacology of Cordia dichotoma (Indian cherry): a review. Asian Pac. J. Trop. Biomed. 3(12):1009-1012. doi:10.1016/S2221-1691(13)60194-X.

Jurjani, A.H. (2010). Zakhira Khawarizm Shahi (Urdu translation by Khan, H.H.). New Delhi: Idarah Kitab al-Shifa,: 5:93-95, 102, 106

Khan, A.J. (1981). A survey of the concepts and measures developed by the Greco-Arab physicians related with the prevention and treatment of the infections and epidemic diseases. Indian J. Hist. Sci., 16:139-144

Koochek, M. H.; Pipelzadeh, M. H. and Mardani, H. (2003). The effectivenes of Viola odorata in the prevention and treatment of formalininduced lung damage in the rat. J. Herbs Spices Med. Plants, 10(2): 95-103. doi:10.1300/J044v10n02_11

Lai, W. L.; Chuang, H. S.; Lee, M. H.; Wei, C. L.; Lin, C. F. and Tsai, Y. C. (2012) Inhibition of herpes simplex virus type 1 by thymol-related monoterpenoids. Planta Med., 78(15):1636-1638. doi:10.1055/ s-0032-1315208

Li Y; Liu X; Guo L; Li J; Zhong D; Zhang Y; Clarke M. and Jin, R. (2020) Traditional Chinese herbal medicine for treating novel coronavirus (COVID-19) pneumonia: Protocol for a systematic review and metaanalysis. Syst. Rev., 9(1):75. doi: 10.1186/s13643-020-01343-4.

Li, G.; Fan, Y.; Lai, Y.; Han, T.; Li, Z. and Zhou, P. (2020). Coronavirus infections and immune responses. J. Med. Virol., 92(4):424-432. doi:10.1002/ jmv.25685.
Lim, S. H. and Choi, C. I. (2019). Pharmacological properties of Morus nigra L. (Black mulberry) as a promising nutraceutical resource. Nutrients, 11(2):437.doi:10.3390/nu 11020437.

Loizzo, M.R.; Saab, A.M.; Tundis R.; Statti, G.A; Menichini, F.; Lampronti, I.; Gambari R; Cinatl, J. and Doerr, H.W. (2008). Phytochemical analysis and in vitro antiviral activities of the essential oils of seven Lebanon species. Chem. Biodivers., 5(3):461-470. doi: 10.1002/ cbdv. 200890045 .

Luo H.; Tang Q.; Shang Y.; Liang S.; Yang M.; Robinson N. and Liu, J.P. (2020). Can Chinese medicine be used for prevention of coronavirus disease 2019 (COVID-19)? A review of historical classics, research evidence and current prevention programs. Chin. J. Integr. Med., 26(4):243-250. doi: 10.1007/s11655-020-3192-6.

Lythgoe, M.P. and Middleton, P. (2020). Ongoing clinical trials for the management of the COVID-19 pandemic. Trends Pharmacol. Sci., 41(6):363-382. doi:10.1016/j.tips.2020.03.006

Mardani, R.; Ahmadi Vasmehjani, A.; Zali, F.; Gholami, A.; Mousavi Nasab, S.D.; Kaghazian, H.; Kaviani, M. and Ahmadi, N. (2020). Laboratory parameters in detection of COVID-19 patients with positive RTPCR; a diagnostic accuracy study. Arch. Acad. Emerg. Med., 8(1):43.

Miccadei, S.; Masella, R.; Mileo, A. M. and Gessani, S. (2016). Polyunsaturated fatty acids as immunomodulators in colorectal cancer: New potential role in adjuvant therapies. Front. Immunol. 7:486. doi:10.3389/fimmu.2016.00486

Nikhat, S. and Fazil, M. (2020). Overview of COVID-19; its prevention and management in the light of Unani medicine. Sci. of the Tot. Environ., 728:1-9. DOI:10.1016/j.scitotenv.2020.13885.

Ober, W.B. and Aloush, N., (1982). The plague at Granada, 1348-1349: Ibn Al-Khatib and ideasof contagion. Bull. N. Y. Acad. Med., 58:418424.

Oza, M.J. and Kulkarni, Y.A. (2017). Traditional uses, phytochemistry and pharmacology of the medicinal species of the genus Cordia (Boraginaceae). J. Pharm. Pharmacol. https://doi.org/10.1111/ jphp. 12715 .

Razi, A.B.M.Z. (2008). Kitab al-Hawi, Vol. 23. (Urdu translation by CCRUM). New Delhi: Central Council for Research in Unani Medicine, Ministry of $\mathrm{H}$ and FW, Govt. of India, pp:149.

Reichling, J. and Schnitzler, P. (2011) Antiviral effects of essential oils used traditionally in phytomedicine. Herbal medicines: Development and Validation of Plant-derived Medicines for Human Health, pp:317.

Rothan, H.A. and Byrareddy, S.N. (2020). The epidemiology and pathogenesis of coronavirus disease (COVID-19) outbreak. J. Autoimmun., 109:102-433. doi:10.1016/j.jaut.2020.102433.

Samarqandi, N. (2010). Sharah Asbab. Aijaz Publishing House, New Delhi.

Sina, I. (2010). Al-Qanoon fi'l Tib, Vol. 4. (Urdu translation by Kantoori GH). New Delhi: Ejaz Publishing House,: 1205, 1208, 1212, 1282

Sohail, MI.; Siddiqui A.; Erumc, N. and Kamran, M. (2021) Phytomedicine and the COVID-19 pandemic. Phytomedicine: A Treasure of Pharmacologically Active Products from Plants https://doi.org/ 10.1016/B978-0-12-824109-7.00005-4. 
Sun, P.; Lu, X.; Xu, C., Sun, W. and Pan, B.(2020). Understanding of COVID19 based on current evidence. J. Med. Virol. https://doi.org/ $10.1002 / j \mathrm{jm} .25722$.

Vairappan, C.S.; Nagappan, T. and Hui, L.T.(2015). Chemical constituents and biological activities of essential oils from four species of bamboo genus Schizostachyum. J. Trop. Biol. Conserv., 12:127136.

Vohora S.B.; Nagvi S.A. and Kumar, H.I. (1980). Antipyretic analgesic and antimicrobial studies on Sismbruym irio. Planta Med., 38:55.

Weeks, J. (2020). Call to action: Announcing the traditional, complementary and integrative health and medicine. COVID-19 Support Registry, 26:1-3. https://doi.org/10.1089/acm.2020. 29083.jjw

World Health Organization (2021). Coronavirus disease (COVID-19) https:/ /www.who.int/health-topics/coronavirus\#tab=tab_1 (Accessed in November 2021).

World Health Organization (2020). Coronavirus disease 2019 (COVID-19) situation report-94. World Health Organization. (https:// www.who.int/docs/default-source/coronaviruse/situation-reports/ 20200423-sitrep-94-COVID-19.pdf, accessed on Nov, 2021)

Yang P. and Wang X. (2020). COVID-19: A new challenge for human beings. Cell Mol. Immunol., 17(5):555-557. doi: 10.1038/s41423-0200407-x.

Yuki, K.; Fujiogi, M. and Koutsogiannaki, S. (2020). COVID-19 pathophysiology: A review. Clin. Immunol., 215:108-427. doi: 10.1016/j.clim.2020.108427.

Zaia, M. G.; Cagnazzo, T.; di, O.; Feitosa, K.A.; Soares, E.G. and Faccioli, L.H. (2016). Anti-inflammatory properties of menthol and menthone in Schistosoma mansoniinfection. Front. Pharmacol., 7:170. doi:10.3389/fphar.2016.00170.

Zhang, K. (2020). Is traditional Chinese medicine useful in the treatment of COVID-19?. The American J. Emer. Med., 38(10):2238. https:/ /doi.org/10.1016/j.ajem.2020.03.046.

Zowalaty, M.E. and Jarhult J.D. (2020). From SARS to COVID-19: A previously unknown SARS-related coronavirus (SARS-CoV-2) of pandemic potential infecting humans. Call for a one health approach. Int. J. One Health, 9:10-16.

Mohd. Kashif Husain (2021). COVID-19 pandemic: A narrative review on possible prophylactic role of AYUSH- 